\title{
Kesiagaan dalam Perencanaan Anggaran Penanggulanan Bencana Banjir di Kabupaten Bandung
}

\author{
${ }^{1}$ Ririn Karlina \\ ${ }^{1}$ UIN Sunan Gunung Djati Bandung; ririnkrlna1@gmail.com
}

\begin{abstract}
The main problem of this research is that there is no special budget for flood disaster management in Cibiru Hilir Village. This study aims to analyze the design of village funds in flood disaster management and analyze village efforts to raise additional funds for flood disaster management in Cibiru Hilir village. The research method used is descriptive qualitative. Collecting data using interviews, observation, and documentation study. Data analysis was carried out, namely data reduction, data presentation, and concluding. The results of this study indicate that the embodiment of the principle of transparency is quite well implemented with the ease of expressing opinions and openness, the accountability process for budget management issued, accountability to the public, and follow-up on irregularities by the rules, and the application of value for money in 2020 and 2021. Still not running optimally in the absence of a special budget for flood disaster management and 2018 and 2019 it has been running economically and flood disaster management services have been running well.
\end{abstract}

Keyword: Local Government, Transparency, Accountability, Value for Money

\section{Pendahuluan}

Segala kejadian yang mengancam dan mengganggu pada fungsi masyarakat baik sarana prasarana, fasilitas umum, terusiknya perekonomian masyarakat, hilangnya nyawa seseorang, maupun segala hal yang mengganggu kehidupan masyarakat dapat dikatakan bencana (Ramadhan et al., 2019). Menurut Undang-Undang Nomor 24 Tahun 2007 tentang Penanggulangan Bencana, bencana adalah kejadian atau rangkaian peristiwa yang meneror dan mengganggu kehidupan dan penghidupan masyarakat yang disebabkan, baik oleh faktor alam dan/atau faktor nonalam maupun faktor manusia sehingga dapat mengakibatkan timbulnya korban jiwa manusia, kerusakan lingkungan, kerugian harta benda, dan dampak psikis. Menurut Kepmen No. 17/Menko/Kesra/x/95 (Keputusan Menteri Koordinator Bidang Kesejahteraan Rakyat, 1995) bencana adalah peristiwa yang disebabkan oleh alam, manusia, dan/atau keduanya yang memberikan akibat korban dan kesusahan umum, serta menyebabkan gangguan terhadap tata penghidupan masyarakat (Nurdinawati, 2019).

Sementara menurut (Usiono et al., 2018), bencana yakni sebuah kejadian atau peristiwa yang tidak biasa yang terjadi karena disebabkan oleh alam maupun ulah manusia, dan termasuk pula di dalamnya terdapat imbas dari kerusakan teknologi yang membuat respon dari masyarakat, individu, komunitas, maupun lingkungan untuk memberikan antusiasme yang bersifat luas. Berdasarkan pengertian-pengertian diatas, bencana adalah segala peristiwa/ kejadian yang disebabkan oleh ulah manusia, alam, atau keduanya dan menimbulkan kerugian seperti korban jiwa dari masyarakat itu sendiri, harta benda masyarakat, alat- alat umum dan atau fasilitas umum, serta memicu respon dari masyarakat itu sendiri. Jenis-jenis bencana 
meliputi; puting beliung, banjir, tanah longsor, kebakaran hutan dan lahan, kekeringan, letusan gunung api, gelombang pasang/abrasi, gempa bumi, gempa bumi dan tsunami, dan tsunami.

Menurut Undang-Undang Nomor 24 Tahun 2007 pasal 1 ayat (2) tentang penanggulangan bencana, banjir merupakan serangkaian peristiwa dari bencana alam. Banjir merupakan salah satu bencana yang dapat terjadi karena faktor alam ataupun non-alam. Karena faktor alam biasanya banjir terjadi akibat hujan lebat dan pasang naik air laut. Sedangkan karena faktor non-alam, banjir biasanya terjadi akibat daerah resapan air tidak ada, kurangnya kapasitas tampung sungai dan sistem drainase, serta rusaknya daerah hulu ataupun hutan. Banjir sendiri terbagi atas beberapa jenis, yakni (1) banjir air yang terjadi karena meluapnya air sungai, air danau, dan air got akibat tingginya curah hujan; (2) banjir Cileuncang atau juga dikenal banjir dadakan yang terjadi karena tingginya curah hujan; (3) banjir ROB yang terjadi karena pasangnya air laut sehingga menyebabkan tertahannya aliran sungai dan jebolnya tanggul; (4) banjir lahar dingin yang terjadi karena keluarnya lahar dingin dari gunung yang sedang erupsi; (5) banjir lumpur yang terjadi karena keluarnya lumpur dari perut bumi yang mengandung bahan dan gas kimia berbahaya; (6) banjir hulu yang terjadi karena cepatnya aliran air di daerah yang sempit (Suharno, 2018).

Berdasarkan hasil observasi peneliti, desa Cibiru Hilir merupakan daerah rawan bencana yang disebabkan oleh ulah masyarakat maupun alam. Salah satu jenis bencana yang sering terjadi di desa Cibiru Hilir adalah banjir air yang terjadi ketika hujan lebat dan saluran sungai yang dangkal, mengakibatkan jebolnya tanggul yang ada. Genangan terparah berada di wilayah Komplek Asrama Polisi dan Komplek Bumi Harapan. Genangan air tersebut masuk ke dalam rumah dan merusak alat-alat rumah tangga. Selain itu, dilansir dari portal berita Sumedang Online (SO) menyatakan bahwa terdapat 1500 rumah di Cibiru Hilir terendam banjir pada tahun 2016 akibat hujan lebat serta meluapnya Sungai Cipariuk yang tidak dapat menampung volume air. Pemerintah desa Cibiru Hilir mengupayakan untuk meminimalisir dampak banjir tersebut dengan menggunakan anggaran dana desa.

Peneliti menjadikan objek penelitian di Desa Cibiru Hilir karena Desa Cibiru Hilir merupakan salah satu dari 7 titik terendah cekungan Bandung sehingga aliran airnya kurang lancar dan berpotensi tinggi terjadi banjir saat musim hujan. Maka, tidak heran apabila Desa Cibiru Hilir sering terjadi banjir ketika hujan turun dengan intensitas yang tinggi (Somantri, 2020).

Berdasarkan hasil wawancara peneliti terhadap warga komplek Bumi Harapan yakni Ibu Maulani, bahwa warga telah menyampaikan kritik terhadap pemerintah desa terkait bencana banjir. Ada warga yang mengetahui prioritas dana desa untuk apa saja dan mengetahui dana desa tersebut tidak di prioritaskan untuk penanggulangan bencana banjir secara khusus. Ada pula warga yang tidak mengetahui prioritas dana khusus penanggulangan bencana banjir.

Undang-Undang Nomor 6 Tahun 2014 tentang desa beserta pelaksanaannya memberikan amanat terhadap pemerintah desa untuk lebih mandiri dalam mengatur dan mengelola pemerintahan, pembangunan, peningkatan kesejahteraan masyarakat, dan segala sumber daya yang dimiliki tidak lain di dalamnya adalah Pengolahan Keuangan (Arenawati, 2016). Dimana pemerintah desa diberikan wewenang dan sumber dana yang memadai dalam merencanakan dan mengelola yang dimiliki desa guna kesejahteraan masyrakatnya. Pemerintah desa harus mengelola dan merencanakan keuangan desa secara transparan, partisipatif, akuntabel, serta disiplin dan tertib. Transparan artinya dalam pengelolaan dan penyampaian keuangan harus terbuka untuk meningkatkan efektifitas pengawasan masyarakat terhadap pelayanan dan pembangunan program, partisipatif artinya dalam penyusunannya dan pengelolaannya harus melibatkan masyarakat untuk menjaga keterbukaan terhadap masyarakat, dan akuntabel artinya 
dalam pengelolaan dan penyusunannya dapat dipertanggungjawabkan secara hukum untuk hasil yang dapat dipercaya oleh masyarakat (Rahajeng, 2016).

Perencaaan adalah suatu proses dalam mendeskripsikan atau menjelaskan tujuan organisasi, membuat strategi dalam mencapai tujuan tersebut, dan mengembangkan rencana organisasi. Sebagai fungsi utamanya, semua program yang disusun tidak akan terlepas dari rencana. Berhasil tidaknya program manusia ditentukan oleh rencana tersebut dibuat (Anantha \& Elmizan, 2015). Perencanaan secara konvensional adalah memperhatikan keadaan sekarang untuk keadaan masa mendatang menjadi lebih baik dengan proses kegiatan tersebut (Engkus et al., 2020). Sedangkan anggaran adalah rencana tertulis kuantitatif mengenai sebuah program dalam suatu organisasi, yang pada umumnya disebutkan dalam satuan angka/uang maupun barang dan jasa (Kaharti, 2019).

Perencanaan anggaran adalah suatu proses dalam program untuk menyusun rencana pendapatan, pembiayaan, dan belanja dalam jangka waktu yang sudah ditentukan. Perencanaan anggaran adalah sebuah rencana dari program yang berisi pengeluaran biaya pada satu waktu tertentu untuk mencapai tujuan yang telah di tetapkan secara maksimal. Dalam tahap perencanaan anggaran ini, pemerintah desa wajib melibatkan masyarakat desa yang diwakili oleh Badan Permusyawaratan Desa (BPD), sehingga setiap kegiatan dan program kerja yang disusun dapat memenuhi kebutuhan masyarakat desa sesuai kapasitas yang dimiliki desa.

Dana desa adalah dana bersumber dari APBN yang di transfer melalui APBD Kota/ Kabupaten serta memiliki segala hak dan kewajiban dalam mengatur penyelenggaraan pemerintah, pembinaan kemasyarakatan, pemberdayaan masyarakat, dan pelaksanaan pembangunan desa (Novianto, 2019). Pelimpahan dana desa yang besar akan menjadi tanggung jawab yang besar juga bagi pemerintahan desa itu sendiri. Maka dari itu, pemerintah desa wajib menerapkan akuntabilitas dalam pemerintahannya, dimana setiap program penyelenggaraan pemerintah desa wajib dipertanggungjawabkan kepada masyarakat sesuai aturan.

\section{Gambar 1}

Data Dana Desa Cibiru Hilir dari Tahun 2016-2019

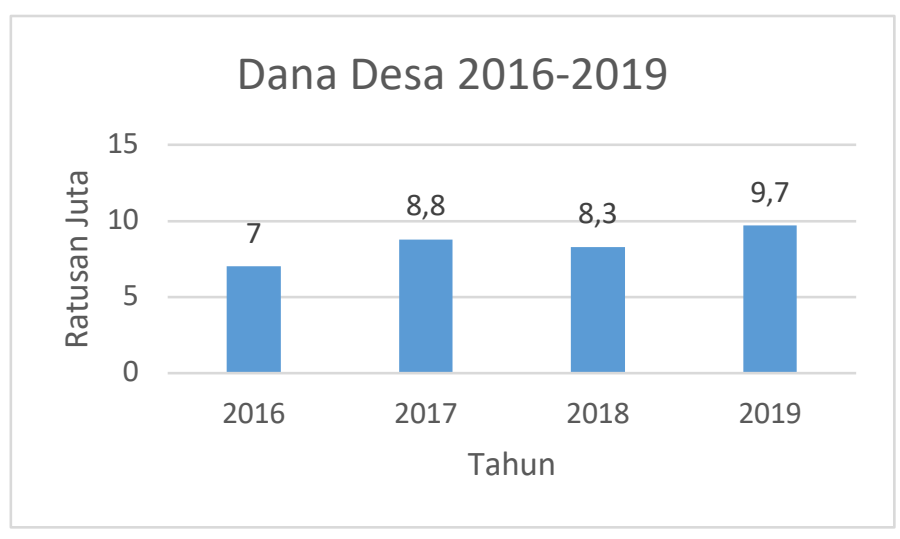

Sumber: Kantor Desa Cibiru Hilir, 2020

Pada Gambar 1 dapat disimpulkan bahwa anggaran dana desa setiap tahunnya cenderung meningkat. Anggaran untuk penanggulangan bencana banjir sendiri dimulai pada tahun 2018, 
karena pada tahun 2016 dan tahun 2017 anggaran tersebut dialokasikan sebagian besar untuk Badan Usaha Milik Desa (BUMDES). Dana desa pada tahun 2016 berjumlah Rp 700.515.725, anggaran tersebut dialokasikan untuk BUMDES. Dana desa pada tahun 2017 berjumlah Rp 883.167.000, anggaran tersebut dialokasikan untuk BUMDES. Dana desa pada tahun 2018 berjumlah $\mathrm{Rp}$ 835.989.000, anggaran tersebut mulai teralokasikan untuk penanggulangan bencana banjir, seperti: Normalisasi Drainase, dan Pelatihan Kesiapsiagaan Masyarakat Desa dalam Menghadapi Bencana Alam. Dan dana desa pada tahun 2019 berjumlah Rp 978.087.000 dialokasikan untuk penanggulangan bencana banjir, seperti: pengadaan mesin penyedot air, dan normalisasi drainase.

Tabel 1

Anggaran Dana Desa Untuk Penanggulangan Bencana Banjir

\begin{tabular}{ccl}
\hline Tahun & Jumlah anggaran dana desa & \multicolumn{1}{c}{ Keterangan } \\
\hline 2018 & Rp 835.989.000 & Normalisasi Drainase (Rp 50.000.000) \\
& Pelatihan Kesiapsiagaan Masyarakat Desa dalam \\
& Menghadapi Bencana Alam (Rp 25.000.000) \\
2019 & Pengadaan Mesin Penyedot Air 4 buah (Rp \\
& 80.000.000) \\
& Normalisasi Drainase (Rp 50.000.000) \\
\hline
\end{tabular}

Sumber: Kantor Desa Cibiru Hilir, 2020

Dari tabel 1.1 dapat disimpulkan bahwa dari sekian ratus juta dana desa dari tahun 20162019 baru tersalurkan anggaran untuk penanggulangan bencana banjir sejak tahun 2018 . Anggaran penanggulangan bencana banjir yang diterima pada tahun 2018 hanya tersalurkan 8,9\% dari jumlah keseluruhan dana desa, dan pada tahun 2019 tersalurkan 13,2\% dari jumlah keseluruhan dana desa. Hal tersebut berarti tidak terdapat anggaran khusus untuk penanggulangan bencana banjir di Desa Cibiru Hilir.

Pemerintah desa Cibiru Hilir membutuhkan kesiagaan atau strategi perencanaan anggaran untuk penanggulangan bencana banjir yang datang dengan tidak diharapkan. Strategi adalah suatu cara dimana lembaga/ organisasi dapat mencapai tujuannya sesuai dengan ancaman dan peluang terhadap lingkungan luar yang akan dihadapi beserta kapasitas dan sumber daya. Menurut Rangkuti (Rangkuti, 2004) strategi adalah suatu alat dalam mencapai tujuan perusahaan, dengan tujuan berjangka waktu panjang, program berkelanjutan, dan mengutamakan alokasi sumber daya. Hal ini sebagai antisipasi pemerintah desa jikalau terjadi sesuatu yang tidak diharapkan untuk menambahkan anggaran penanggulangan bencana banjir yang membutuhkan biaya yang cukup besar.

Strategi anggaran adalah suatu proses menentukan rencana anggaran untuk tujuan jangka panjang, diikuti penyusunan upaya bagaimana agar tujuan tersebut dapat tercapai. Strategi pada umumnya untuk menjangkau masa depan, sehingga dalam penyusunannya dilakukan secara bertahap, hati-hati dan memperthitungkan hal-hal yang dapat mempengaruhinya agar sasaran dan strategi dapat tercapai secara baik dan benar. Pembuatan strategi anggaran untuk mencapai visi dan misi Desa Cibiru Hilir. Pemerintah desa Cibiru Hilir harus mengidentifikasi ancaman, kecendrungan, dan peluang, dimana kemungkinan hasilnya dapat mengubah kecendrungan historis. Proses penyusunan anggaran berfokus pada jangka waktu satu tahun, sedangkan perencanaan strategi fokus pada program yang mencakup beberapa tahun. Penyusunan anggaran ini di dahului oleh perencanaan strategi. Pembuatan anggaran merupakan bagian dari proses perencanaan strategi. Apabila pemerintah desa memiliki perencanaan strategi yang 
buruk, maka anggaran pun akan mengalami permasalahan atau hal yang sama. Anggaran merupakan suatu alat untuk mencapai tujuan dan sasaran dari organisasi atau pemerintah desa.

Sebelum ditetapkannya rencana anggaran, maka rencana strategi harus dibuat, dimana dalam perencanaan strategi ditujukan dalam jangka waktu panjang atau masa depan. Untuk jangka waktu lima tahun biasanya rencana strategi dibuat, yang dapat memberikan konsekuensi dari kegiatan atau program yang dibuat sekarang. Pemerintah desa dapat mengartikan semua strategi dalam jangka panjang dan pendek, agar tujuan tersebut sebagai dasar pembuatan suatu anggaran. Hal tersebut dapat menaikan hubungan yang kokoh antara perencanaan strategi dan anggaran, dimana dapat membantu manajeman untuk tidak terfokus pada jangka pendek saja, karena anggaran merupakan perencanaan dalam satu periode saja.

Pemerintah desa atau organisasi harus bertindak professional dalam mencapai tujuan. Anggaran dapat pula dikatakan rencana, yaitu rencana yang dibuat secara tersusun dalam bentuk angka dan dinyatakan dalam suatu unit moneter dalam jangka waktu di masa depan bagi suatu program atau kegiatan. Di dalam sebuah program, anggaran menjadi unit yang sangat penting untuk menopang atau menjalankan program tersebut, anggaran dapat membantu berjalannya suatu program, terutama program penanggulangan bencana banjir yang membutuhkan modal yang tidak sedikit. Anggaran diharapkan dapat membantu memanajemen untuk mengendalikan dan melaksanakan operasional pemerintahan desa atau organisasi. Menurut peneliti untuk menunjang kegiatan berjalan secara maksimal, dalam penyusunan anggran harusnya bersifat realistis, terus dicermati, dan luwes. Anggaran memberikan salah satu jaminan terhadap berjalannya program penanggulangan bencana banjir ini, dengan demikian maksud dari penyusunan anggaran adalah memberikan jaminan terhadap pencapaian program baik dalam jangka waktu pendek maupun jangka waktu panjang.

Untuk menunjang kebutuhan program penanggulangan bencana maka akan membutuhkan keuangan negara. Menurut Undang-Undang No. 17 Tahun 2003, keuangan negara adalah semua kekayaan negara, yang di dalamnya harta milik kekayaan itu dan segala hak dan kewajiban yang muncul karenanya, baik kekayaan yang dalam pengurusan pejabat atau lembaga pemerintah, maupun yang berada dalam pengurusan bank pemerintah, dengan status hukum publik (Ihyaul Ulum, 2008).

Penelitian ini menggunakan tiga prinsip, yaitu transparansi, akuntabilitas, dan value for money sebagaimana dalam (Damayanty, 2016). Secara terperinci tiga dimensi sebagai berikut: (1) Prinsip transparansi, untuk mengukur transparansi tersebut peneliti menggunakan teori Widodo (2001) yang menyebutkan bahwa indikator transparansi yakni kemudahan dalam mengakses informasi sehingga masyarakat mudah mengakses informasi melalui internet atau website; mekanisme dalam penyampaian pendapat dipermudah melalui internet; memberikan kesempatan bagi masyarakat terbuka untuk mengajukan kritik dan tanggapan program penanggulangan bencana yang dinilai tidak transparan. (2) Prinsip akuntabilitas, untuk mengukur akuntabilitas tersebut peneliti menggunakan teori Lembaga Administrasi Negara (2007) yang menyebutkan bahwa indikator akuntabilitas yakni, pengelolaan anggaran yang dikeluarkan harus bersifat akuntabel dengan sesuai aturan yang berlaku; pertanggungjawaban dalam kinerja; intensitas penyimpangan korban penanggulangan bencana; upaya terhadap tindak lanjut dari program penanggulangan bencana. (3) Prinsip value for money, untuk mengukur value for money tersebut peneliti menggunakan teori Mardiasmo (2009) yang menyebutkan bahwa indikator value for money ini yakni, alokasi biaya dilihat dari ekonomi dan efisien; dan kualitas pelayanan dilihat dari efektivitas.

Pada penelitian terdahulu tentang dana desa oleh Widayanti \& Aco (2019) berjudul "Pemanfaatan Dana Desa (DD) di Desa Argomulyo Kecamatan Cangkringan Kabupaten 
Sleman" penelitian ini menjelaskan pemanfaatan Dana Desa di bidang pembangunan desa dan pemberdayaan masyarakat. Penelitian ini menggunakan metode deskriptif kualitatif. Hasil yang diperoleh dari penelitian ini adalah transparansi cukup baik, partisipatif cukup baik, dapat dinikmati masyarakat baik, akuntabilitas baik, dan berkelanjutan baik. Penelitian lain yang dibahas oleh Esa Yulia Damayanti (2016) berjudul "Kinerja Pengelolaan Keuangan dalam Program Pencegahan Dini dan Penanggulangan Korban Bencana Alam di BPBD Kabupaten Trenggalek". Membahas kinerja pengelolaan keuangan dalam program pencegahan dini dan penanggulangan korban bencana alam. Penelitian ini menggunakan metode penelitian kualitatif. Hasil dari penelitian ini adalah akuntabilitas dan transparansi anggaran sudah dilakukan dengan baik, akan tetapi proses penganggaran secara manual masih rawan terjadi penyimpangan anggaran, dan perwujudan value for money sudah berjalan dengan baik (Damayanty, 2016).

Penelitian terdahulu selanjutnya oleh Ulrike Kornek dan Ottmar Edenhofer (2020) berjudul "The strategic dimension of financing global public goods" penelitian ini menjelaskan tentang salah satu tantangan dalam mengatasi masalah lintas batas seperti perubahan iklim adalah insentif untuk tumpangan gratis. Penelitian ini memeriksa bagaimana dana semacam itu dapat berubah insentif untuk tumpangan gratis dalam permainan barang publik global. Hasil penelitian ini adalah (1) total penyediaan barang publik lebih tinggi ketika mereka yang berkontribusi diberi lebih banyak kompensasi; dan (2) non-partisipasi dalam dana dapat dihukum jika anggota yang tersisa mengurangi persediaan barang publik mereka secara memadai (Kornek \& Edenhofer, 2020).

Berdasarkan penjabaran di atas maka peneliti akan melakukan penelitian tentang Kesiagaan dalam Perencanaan Anggaran Penanggulangan Bencana Banjir di Desa Cibiru Hilir. Tujuan penelitian adalah menganalisis rancangan dana desa dalam penanggulangan bencana banjir dan menganalisis upaya desa dalam menghimpun dana tambahan bagi penanggulangan bencana banjir di desa Cibiru Hilir.

\section{Metode Penelitian}

Metode penelitian yang dilakukan pada penelitian ini menggunakan metode penelitian deskriptif dan pendekatan penelitian kualitatif. Menurut Denzin \& Lincoln (1994) (Anggito, 2018) penelitian kualitatif bertujuan menafsirkan fenomena yang terjadi dengan menggunalakan latar belakang alamiah dan dilakukan dengan melibatkan berbagai metode yang ada. Penelitian ini menggunakan metode penelitian deskriptif, menurut Mely G. Tan (Silalahi, 2015) penelitian deskriptif adalah penelitian yang bertujuan menjelaskan dan atau mendeskripsikan suatu hal dengan sebenarnya dan tepat sifat suatu individu, kejadian, gejala, atau organisasi tertentu, dan untuk menentukan suatu frekuensi atau penyebaran gejala adanya hubungan tertentu dalam masyarkat.

Pengumpulan data dalam penelitian ini menggunakan metode wawancara, observasi, dan studi dokumentasi. Wawancara adalah percakapan yang dilakukan secara terstruktur dan terorganisir yang dilakukan oleh peneliti kepada responden untuk mendapatkan informasi yang berkaitan dengan masalah penelitian (Silalahi, 2015). Observasi adalah pengamatan dengan mencatat secara sistematis terhadap gejala yang diteliti. Studi dokumentasi adalah pengambilan data melalui dokumen-dokumen (Hardani et al., 2017). Adapun yang menjadi informan dalam penelitian ini adalah Aparatur Desa Cibiru Hilir.

Tabel 2

Data Informan Penelitian 


\begin{tabular}{lcc}
\hline No & Nama & Jabatan \\
\hline 1. & GNS & Sekertaris Desa Cibiru Hilir \\
2. & TS & Kepala Dusun 4 \\
3. & ID & Ketua RW 10 \\
4. & IV & Ketua RW 17 \\
\hline \multicolumn{2}{c}{ Sumber: Hasil Penelitian (Diolah peneliti), 2021 }
\end{tabular}

Keterangan:

1. Informan Kunci: GNS

2. Informan Utama: TS

3. Informan Pendukung: ID dan IV

4.

Analisis data yang dilakukan diambil menurut Huberman dan Miles yakni reduksi data, penyajian data, dan penarikan kesimpulan. Reduksi data adalah suatu proses pemilihan, pemusatan data menjadi sederhana, dan transformasi data kasar yang muncul dari catatan yang tertulis di lapangan. Penyajian data adalah sekumpulan informasi yang tersususn yang memberikan kesempatan untuk penarikan kesimpulan. Penarikan kesimpulan adalah rangkuman dan hasil keseluruhan dari catatan-catatan yang telah diteliti (Silalahi, 2015).

Tabel 3

Tabel Operasional Variabel

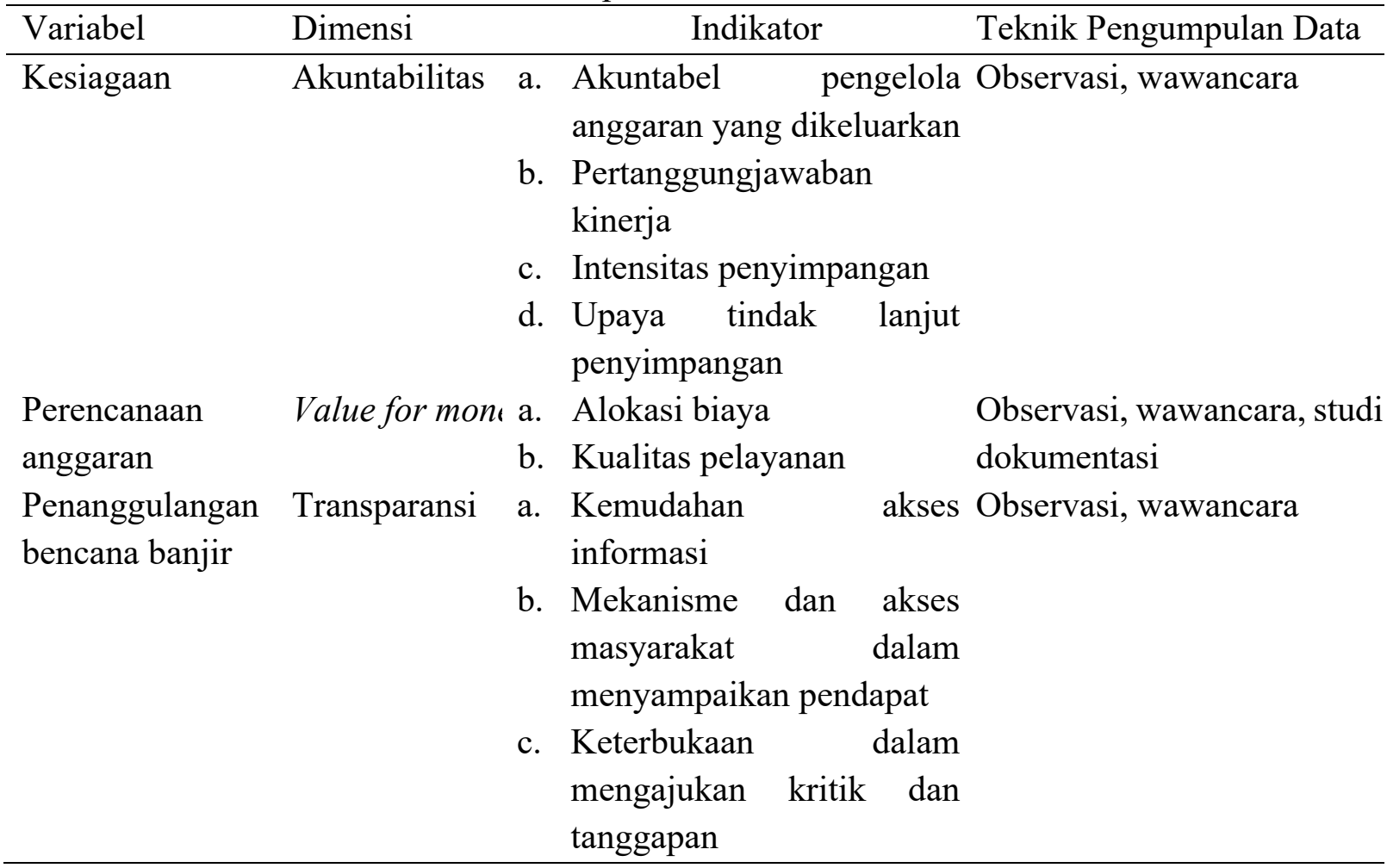

Hasil dan Pembahasan

\section{Kesiagaan Perencanaan Anggaran}

Pada tahun 2018 Pemerintah Desa Cibiru Hilir telah mengajukan bantuan kepada Pemerintah Daerah (Kabupaten) untuk membantu formula mengatasi banjir seperti; sumur retensi, dan pompa dengan ukuran besar. Dusun 4 merupakan daerah genangan terparah yang dapat mencapai 3-4 hari bahkan sampai dengan 7 hari. Dusun 4 merupakan wilayah perumahan 
dan cukup sulit menangani bencana banjir tersebut karena sudah terbangun infrastruktur. Akan tetapi dengan adanya sumur retensi dan pompa cukup meminimalisir bencana banjir meski belum sepenuhnya teratasi. Pada tahun 2020 dana kebencanaan terserap untuk keperluan bencana pandemi Covid-19, dan di tahun 2021 banjir menjadi peta kerawanan. Peta ini awalnya akan digunakan untuk mengevaluasi bencana banjir sudah sejauh mana, tapi karena adanya perubahan Undang-Undang yang sering terjadi maka pada tahun 2021 terfokus pada: (1) mengentaskan orang terdampak pandemi berupa tunai; (2) membuat posko-posko; (3) menempatkan orang-orang tertentu yang menjadi agen informasi yakni gugus tugas.

Hasil musyawarah besar pemerintah desa 2021 sepakat bahwa anggaran terfokus pada pandemi Covid-19 yang pada akhirnya untuk anggaran kebencanaan menggunakan dana emergency, tidak ada penambahan anggaran dan digunakan untuk keadaan mendesak saja. Pemerintah desa mengandalkan cadangan dana darurat ini dari APBD, dan anggaran APBDes juga kosong karena digunakan untuk keperluan pandemi.

\section{Akuntabilitas}

Akuntabilitas merupakan keterampilan dari organisasi sektor publik dalam memberikan kepastian terhadap langkah-langkah yang dilakukannya terutama terhadap kelompokkelompok yang dalam sistem politik telah diberikan kekuasaan untuk melakukan penilaian dan evaluasi terhadap organisasi publik tersebut (Kusumasari et al., 2015). Untuk mengukur akuntabilitas Lembaga Administrasi Negara (2007) yang menyebutkan bahwa indikator akuntabilitas yakni, pengelolaan anggaran yang dikeluarkan harus bersifat akuntabel dengan sesuai aturan yang berlaku; pertanggungjawaban dalam kinerja; intensitas penyimpangan penanggulangan bencana; upaya terhadap tindak lanjut dari program penanggulangan bencana.

Perwujudan akuntabilitas sudah cukup berjalan, hal ini selaras dengan yang dikemukakan Novitaningrum (2014) yang berjudul Akuntabilitas dan Transparansi Pengadaan Barang dan Jasa Pemerintah Melalui Electronic Procurement (Best Practice di Pemerintah Kota Surabaya), dimana akuntabilitas dalam penelitian ini telah berhasil diwujudkan dengan mampu mewujudkan suatu sistem yang akuntabel dan dapat dipertanggungjawabkan di setiap tahapan dan dapat mempertanggungjawabkan seluruh proses kegiatan secara vertikal kepada pihak yang lebih tinggi, maupun horizontal kepada masyarakat luas. Adapun penelitian yang dikemukakan Sa'adah (2015) yang berjudul Akuntabilitas Dan Transparansi Anggaran Melalui E-Government (Studi tentang Penganggaran di Pemerintahan Daerah Kabupaten Blitar), dimana akuntabilitas yang dilakukan sudah berjalan cukup baik dengan masyarakat dengan mudah mengakses informasi anggaran, namun pertanggungjawaban vertikal kepada pemerintah juga menjadi aspek akuntabilitas yang dilakukan pemerintah masih terdapat kekurangan.

\section{Akuntabel Pengelolaan Anggaran yang Dikeluarkan}

Anggaran yang dikeluarkan sesuai dengan aturan yang berlaku pada sumber dana yang mengacu pada pagu anggaran, dan jenis kegiatan yang telah dilakukan dan semuanya tertuang pada peraturan kementrian, provinsi, dan kabupaten. Pada tahun 2021 anggaran dana desa terfokus pada pandemi Covid-19, sehingga untuk anggaran kebencanaan tidak menjadi prioritas. Anggaran kebencanaan keluar melalui musyawarah besar desa, dan hasil dari 
pembahasan musyawarah besar bahwa anggaran kebencanaan menggunakan anggaran darurat atau dana darurat. Dana darurat ini turunnya dari Anggaran Belanja dan Belanja Daerah Kabupaten Bandung (APBD). Kemudian pihak Pemerintah Daerah akan memantau di lapangan terlebih dahulu. Setelah itu pihak Perangkat Uji Tanah Rawa (PUTR) akan membantu merenovasi dan memperbaiki bencana banjir tersebut.

\section{Pertanggungjawaban Kinerja}

Pemerintah Desa Cibiru Hilir di akhir tahun akan mengevaluasi program-program yang telah berjalan, hal tersebut dilakukan untuk merencanakan anggaran tahun selanjutnya lebih baik lagi. Misalnya, pada tahun ini ada bencana apa saja yang kemudian di tahun selanjutnya akan dipersiapkan. Pertanggungjawaban vertikal berbentuk pertanggungjawaban laporan, dan pertanggungjawaban horizontal berbentuk pernyataan kesanggupan memelihara dari hasil pekerjaan atas usulan yang telah diajukan oleh masyarakat. Pemerintah desa berupaya berkomunikasi dengan baik dengan Kepala Asrama Polda Jabar, dan dari Pemerintah Desa pun sebatas pendataan, seperti wilayah terkena banjir, ketinggian banjir, dsb. Segala sesuatu tergantung pada ranah Dinas Polda, untuk Masyarakat Sipil maka Pemerintah Desa akan memperhitungkan tempat evakuasi, dan logistik. Dari pihak Aspol sendiri sering mengirimkan bantuan. Dengan adanya retensi air, hal tersebut dapat menekan air cepat surut.

\section{Intensitas Penyimpangan}

Pemerintah Desa Cibiru Hilir mengalami masalah pada anggaran penanggulangan bencana banjir. Anggaran bencana tersebut tidak cukup untuk membiayai perlengkapan logistik sehingga Pemerintah Desa Cibiru Hilir terus berupaya mencukup-cukupkan anggaran yang ada untuk melanjutkan program penanggulangan bencana meski masih belum berjalan secara maksimal.

\section{Tindak Lanjut Penyimpangan}

Pemerintah Desa Cibiru Hilir selalu berupaya berkomunikasi dengan baik dengan pihak Asrama Polda. Dengan kurangnya anggaran kebencanaan, Pemerintah Desa Cibiru Hilir akan mengkomunikasikan kepada pihak Badan Penanggulangan Bencana Daerah Kabupaten Bandung (BPBD) untuk mengirimkan bantuan, bantuan tersebut berupa anggaran darurat atau anggaran emergency, dimana anggaran tersebut berasal dari APBD. Selain itu, pemerintah desa juga menyarankan untuk membuat swadaya masyarakat, maksudnya masyarakat mempersiapkan anggaran tanggap darurat. Aparat wilayah pun menyiapkan anggaran dari kas RT untuk penanggulangan bencana banjir.

\section{Value For Money}

Value for money merupakan konsep penilaian kinerja dalam sektor publik yang memiliki tiga elemen utama yakni, ekonomi, efisien, dan efektivitas. Adapun manfaat dalam pelaksanaan value for money pada organisasi sektor publik yaitu: ekonomis (hemat cermat) dalam alokasi sumber daya, efisien berdaya guna dalam memanfaatkan sumber daya, dan efektif berhasil guna dalam menggapai tujuan (Erawan et al., 2018). Pada tahun 2018 dana belanja kebencanaan 
masuk pada belanja pemberdayaan masyarakat dan pada tahun 2019 dana belanja kebencanaan masuk pada belanja bidang penanggulangan bencana, darurat dan mendesak desa. Rincian data APBDes Desa Cibiru Hilir yang sudah diolah oleh peneliti adalah sebagai berikut:

Tabel 4

Laporan Keuangan 2018

\begin{tabular}{|c|c|c|}
\hline Uraian & Target & Realisasi \\
\hline \multicolumn{3}{|l|}{ PENDAPATAN } \\
\hline Pendapatan Asli Daerah & 75.600 .000$, & 49.100.000, \\
\hline Dana Desa & 883.167 .000$, & 835.989.000, \\
\hline Alokasi Dana Desa & 858.354 .200$, & 841.117.300, \\
\hline Bagi Hasil Pajak Daerah & 126.827.500, & 156.944.400, \\
\hline Bagi Hasil Retribusi Kabupaten & 10.060 .800$, & 10.007.200, \\
\hline Ba.Keu.Khus.Provinsi & 165.000 .000$, & 115.000.000, \\
\hline BKK Kabupaten & 50.000 .000 & 50.000 .000 \\
\hline JUMLAH PENDAPATAN & 2.169.009.500, & 2.058.157.900, \\
\hline \multicolumn{3}{|l|}{ BELANJA } \\
\hline Belanja Penyelenggaraan Pemerintah Desa & 863.115 .000$, & 873.974.500, \\
\hline Belanja Pelaksanaan Pembangunan Desa & $897.000 .000,1$ & 819.830 .000 \\
\hline Belanja Pembinaan Kemasyarakatan Desa & 53.727 .500$, & 122.664.400, \\
\hline Belanja Pemberdayaan Masyarakat Desa & 335.167 .000$, & 231.289.000, \\
\hline Bidang Tak Terduga (PAD) & 20.000 .000$, & 10.400.000, \\
\hline JUMLAH BELANJA & 2.169.009.500, & 2.058.157.900, \\
\hline
\end{tabular}

Sumber: Kantor Desa Cibiru Hilir, 2020

Perwujudan value for money ini sudah berjalan namun masih belum optimal, hal ini selaras dengan yang di kemukakan (Damayanty, 2016) yang berjudul Kinerja Pengelolaan Keuangan dalam Program Pencegahan Dini dan Penanggulangan Korban Bencana Alam di BPBD Kabupaten Trenggalek, dimana pengakolasian biaya sudah berjalan baik sesuai dengan apa yang diinginkan pemerintah dan kualitas pelayanan cukup baik. Adapun penelitian yang dikemukakan Sari (2014) yang berjudul Analisis Pengukuran Kinerja Pemerintah Daerah dengan Menggunakan Prinsip Value For Money (Study Kasus Kabupaten Sumenep Tahun 2010-2013) bahwa penelitian ini berjalan baik, karena hasil perhitungan rasionya dari tahun ke tahun cenderung berada pada katagori ekonomis, efisien dan efektif.

Tabel 5

Laporan Realisasi APBDes Cibiru Hilir Tahun 2019 


\section{Alokasi Biaya}

\begin{tabular}{|c|c|c|}
\hline & ANGGARAN & REALISASI \\
\hline \multicolumn{3}{|l|}{ APATAN } \\
\hline dapatan Asli Daerah & $37.500 .000,00$ & 0,00 \\
\hline dapatan Transfer & $2.286 .686 .000,00$ & $2.286 .686 .000,00$ \\
\hline Jana Desa & $978.087 .000,00$ & $978.087 .000,00$ \\
\hline 3agi Hasil Pajak Dan Retribusi & $162.686 .100,00$ & $162.686 .100,00$ \\
\hline Alokasi Dana Desa & $868.624 .900,00$ & $868.624 .900,00$ \\
\hline 3antuan Keuangan Provinsi & $227.288 .000,00$ & $227.288 .000,00$ \\
\hline 3antuan Keuangan Kabupaten/Kota & $50.000 .000,00$ & $50.000 .000,00$ \\
\hline IUMLAH PENDAPATAN & 2.324.186.000,00 & 2.286.686.000,00 \\
\hline \multicolumn{3}{|l|}{ NJA } \\
\hline ang Penyelenggaraan Pemerintah Desa & $886.028 .500,00$ & $852.828 .500,00$ \\
\hline ang Pelaksanaan Pembangunan Desa & $821.175 .000,00$ & $821.175 .000,00$ \\
\hline ang Pembinaan Kemasyarakatan & $189.582 .500,00$ & $189.582 .500,00$ \\
\hline ang Pemberdayaan Masyarakat & $343.100 .000,00$ & $343.100 .000,00$ \\
\hline Penanggulangan Bencana, Darurat dan Mendes & $84.300 .000,00$ & $80.000 .000,00$ \\
\hline IUMLAH BELANJA & 2.324.186.000,00 & 2.286.686.000,00 \\
\hline ¡URPLUS / (DEFISIT) & $\mathbf{0 , 0 0}$ & $\mathbf{0 , 0 0}$ \\
\hline /SILPA TAHUN BERJALAN & $\mathbf{0 , 0 0}$ & $\mathbf{0 , 0 0}$ \\
\hline
\end{tabular}

Anggaran untuk penanggulangan bencana banjir tidak cukup tapi Pemerintah Desa Cibiru Hilir memanfaatkan dana yang ada karena prioritas dana desa untuk Covid-19. Kebencanaan di wilayah Cibiru Hilir tidak hanya banjir, akan tetapi pemerintah desa cibiru hilir hanya menyediakan dana darurat untuk banjir saja. Kebencanaan yang lain dianggap dapat diantisipasi tingkat masyarakat sendiri. Pemerintah Desa pun telah berusaha dalam menggunakan anggaran bencana banjir dengan membeli logistik, selama tidak terjadi keadaan tak terduga. Pengalokasian anggaran kebencanaan sesuai dengan rencana, namun pada saat pelaksanaannya mengalami minus anggaran sehingga harus menggunakan anggaran dana darurat dari APBD. Alokasi biaya dilihat dari sisi ekonomis dan efisien. Pada tahun 2018 dan 2019 alokasi biaya untuk penanggulangan bencana banjir adalah hemat dan efisien, sesuai berdasarkan rumus:

\section{Rasio Ekonomis dapat dihitung dengan rumus:}

$$
\begin{gathered}
\text { Rasio Ekonomis }=\frac{\text { realisasi pengeluaran }}{\text { anggaran pengeluaran }} \times 100 \% \\
2018=\frac{231.289 .000}{335.167 .000} \times 100 \%=69 \% \\
2019=\frac{80.000 .000}{84.300 .000} \times 100 \%=94,89 \%
\end{gathered}
$$

Ketentuan:

Jika $<100 \%$ berarti ekonomis 
Jika $>100 \%$ berarti tidak ekonomis

$\mathrm{Jika}=100 \%$ berarti ekonomis berimbang

Rasio Efisiensi dapat dihitung dengan rumus:

$$
\begin{gathered}
\text { Rasio Efisiensi }=\frac{\text { realisasi pengeluaran }}{\text { realisasi pendapatan }} \times 100 \% \\
2018=\frac{231.289 .000}{835.989 .000} \times 100 \%=27,6 \% \\
2019=\frac{80.000 .000}{978.087 .000} \times 100 \%=8,17 \%
\end{gathered}
$$

Keterangan:

Jika $<100 \%$ berarti efisien

Jika $>100 \%$ berarti tidak efisien

Jika $=100 \%$ berarti efisien berimbang

\section{Kualitas Pelayanan}

Setiap ada pelaporan dari masyarakat kepada pemerintah desa jika dapat ditangani oleh pemerintah desa maka pemerintah desa akan mengeluarkan anggaran. Akan tetapi jika tidak bisa, pemerintah desa akan melakukan koordinasi dengan dinas-dinas penanggulangan bencana, seperti BPBD dan PUTR. Penyelenggaraan pelayanan penanggulangan bencana banjir di Desa Cibiru Hilir berjalan cukup baik ditandai dengan dapat menekan air cepat surut meski masih belum optimal, karena permasalahan banjir ini masih belum teratasi dengan baik dan intensitas banjir yang sering terjadi. Pemerintah Desa Cibiru Hilir juga telah melaksanakan sosialisasi kebencanaan dari pihak Pemerintah Daerah Kabupaten Bandung, meliputi kesiapsiagaan, pra, dan pelatihan satgas kebencanaan. Kualitas pelayanan ini dilihat dari sisi efektivitas, pada tahun 2018 efektivitas berjalan baik. Pada tahun 2019 efektivitas berimbang.

\section{Rasio Efektivitas dapat dihitung dengan rumus:}

$$
\begin{gathered}
\text { Rasio Efektivitas }=\frac{\text { realisasi pendapatan }}{\text { anggaran pendapatan }} \times 100 \% \\
2018=\frac{835.989 .000}{883.167 .000} \times 100 \%=94,6 \% \\
2019=\frac{978.087 .000}{978.087 .000} \times 100 \%=100 \%
\end{gathered}
$$

Keterangan:

Jika $>100 \%$ berarti efektif

Jika $<100 \%$ berarti tidak efektif

$\mathrm{Jika}=100 \%$ berarti efektivitas berimbang 


\section{Transparansi}

Transparansi merupakan kewajiban setiap pengelola dalam melaksanakan keterbukaan dalam penyampaikan informasi sehingga masyarakat dapat mengetahui dan memiliki akses informasi seluas-luanya. Transparansi publik pada zaman globalisasi menjadi suatu kebutuhan yang krusial bagi masyarakat, transparansi tersebut harus memberikan keterbukaan yang berkaitan dengan informasi terkait perencanaan sumber daya publik kepada kelompokkelompok yang membutuhkan informasi tersebut (Engkus et al., 2019). Untuk mengukur transparansi tersebut Widodo (2001) yang menyebutkan bahwa indikator transparansi yakni kemudahan dalam mengakses informasi; mekanisme dalam penyampaian pendapat; memberikan kesempatan bagi masyarakat terbuka untuk mengajukan kritik dan tanggapan program penanggulangan bencana yang dinilai tidak transparan.

Perwujudan transparansi sudah berjalan, akan tetapi hasil penelitian tersebut berbeda dengan yang di kemukakan oleh Fitrianda (2013) yang berjudul Perilaku Kepala Desa Sebagai Pengelola Dana Desa, dimana pelaksanaan prinsip transparansi yang dilakukan tersebut belum sampai pada taraf ideal terhadap yang diinginkan oleh pemerintah. Hal tersebut karena tindakan-tindakan menyimpang dari kepala desa sebagai pengelola keuangan desa, tindakantindakan tersebut dari faktor internal maupun eksternal dari pemerintahan desa. Adapun penelitian yang dikemukakan oleh Sa'adah (2015) yang berjudul Akuntabilitas Dan Transparansi Anggaran Melalui E-Government (Studi tentang Penganggaran di Pemerintahan Daerah Kabupaten Blitar), dimana transparansi anggaran penelitian tersebut sudah baik dengan memiliki situs resmi transparansi anggaran.

\section{Kemudahan Akses Informasi}

Kemudahan akses dalam mendapatkan informasi dalam penanggulangan bencana banjir di desa cibiru hilir berjalan cukup baik. Pemerintah desa telah menyiapkan website desa untuk menyampaikan informasi, akan tetapi website tersebut masih belum berjalan dengan aktif. Selain itu masyarakat dapat mengetahui informasi dari lembaga desa langsung. Akan tetapi dari pihak pemerintah desa dalam kondisi belum terstruktur dengan baik karena arahan yang selalu berubah saat pandemi seperti ini. Informasi mengenai anggaran bencana banjir pun telah Pemerintah Desa Cibiru Hilir sampaikan kepada Aparatur Wilayah terkait. Pemerintah Desa pun telah menempelkan baliho pendapatan anggaran dan belanja anggaran secara umum di Kantor Desa Cibiru Hilir agar masyarakat tahu pengalokasian anggaran dipergunakan untuk apa saja.

\section{Mekanisme dan Akses Masyarakat dalam Penyampaian Pendapat}

Mekanisme yang dilakukan Masyarakat Desa Cibiru Hilir dalam menyampaikan pendapat penanggulangan bencana banjir dengan cara melaporkan datang langsung ke Kantor Desa Cibiru Hilir. Adapun yang mengadukan keluhan tersebut kepada pihak aparat wilayah yakni Ketua RW dan Ketua RT. Namun untuk mengajukan kritik dan pendapat melaui website LAPOR (Layanan Pengaduan Online Masyarakat) masih belum ada yang menggunakan. 


\section{Keterbukaan}

Keterbukaan untuk Masyarakat Desa Cibiru Hilir diberikan kesempatan untuk mengajukan kritik dan pendapat kepada Pemerintah Desa Cibiru Hilir, dan masyarakat yang berpartisipasi dalam menyampaikan kritik ini terbilang banyak. Namun mengajukan kritik dan pendapat melaui website LAPOR (Layanan Pengaduan Online Masyarakat) masih belum ada yang menggunakan. Pemerintah desa pun sudah dari jauh-jauh hari menyampaikan kepada aparat wilayah terkait jumlah anggaran kebencanaan yang telah dianggarkan. Kemudian aparat wilayah terkait memverifikasi di lapangan dan dibantu lembaga sosial tingkat desa.

\section{Simpulan}

Rancangan penanggulangan bencana banjir di desa cibiru hilir pada tahun 2018 dan 2019 sudah berjalan namun pada tahun 2020 dan tahun 2021 terhambat karena anggaran tersebut dialokasikan kepada penanganan pandemi Covid-19. Adapun upaya desa dalam menghimpun dana tambahan yaitu dengan cara mengkomunikasikan pada pihak Badan Penanggulangan Bencana Daerah (BPBD) Kabupaten Bandung untuk mengirimkan bantuan berupa anggaran darurat yang berasal dari Anggaran Pendapatan dan Belanja Daerah (APBD). Selain itu, pemerintah desa juga menyarankan untuk membuat program swadaya masyarakat, maksudnya masyarakat mempersiapkan anggaran tanggap darurat.

Berdasarkan hal-hal tersebut, peneliti merekomendasikan dalam kesiagan perencanaan anggaran penanggulangan bencana banjir; (1) Pemerintah Desa Cibiru Hilir lebih meningkatkan transparasi perencanaan anggaran dan laporan program penanggulangan bencana banjir secara terperinci dan ter-update karena laporan anggaran 2021 masih belum terpublish. Hal tersebut dapat dilakukan dengan dipublikasikan melalui media sosial yang mudah diakses oleh masyarakat. (2) Pemerintah Desa Cibiru Hilir lebih meningkatkan komunikasi antar pemerintah daerah, aparat wiliyah, dan masyarakat sehingga informasi mengenai perencanaan anggaran penanggulangan bencana banjir tidak hanya sampai pada aparat wilayah saja melainkan masyarakat luas pun harus mengetahuinya. (3) Pemerintah Desa lebih meningkatkan kembali kinerja anggaran agar masyarakat dapat merasakan anggaran tersebut memihak untuk kepentingan masyarakat.

\section{Referensi}

Admin. (2016). 1500 Rumah di Cibiruhilir Terendam Banjir. Sumedang Online. Retrieved from https://sumedangonline.com/2016/06/1500-rumah-di-cibiruhilir-terendambanjir/pages/business.html diakses 1 Januari 2021.

Anantha, A., \& Elmizan, G. H. (2015). Analisis Konsistensi Perencanaan Dan Penganggaran Pada Badan Penanggulangan Bencana Daerah Kabupaten Tanah Datar Tahun 2011-2015 
Dengan Prediksi Kerugian Untuk Tahun 2016-2020. Jurnal KBP, 3(1), 129-145.

Anggara, S. (2016). Ilmu Administrasi Negara (2nd ed.; Beni Ahmad Saebani, Ed.). Bandung: CV Pustaka Setia.

Anggito, A. dan J. S. (2018). Metodologi penelitian kualitatif - Albi Anggito, Johan Setiawan - Google Buku. CV Jejak.

Arenawati. (2016). Administrasi Pemerintahan Daerah; Sejarah, Konsep, dan Penatalaksanaan di Indonesia. Yogyakarta: Graha Ilmu.

Damayanty, E. Y. (2016). Kinerja Pengelolaan Keuangan Dalam Program Pencegahan Dini Dan Penanggulangan Korban Bencana Alam Di BPBD Kabupaten Trenggalek. Repositori Unair, 1-10.

Engkus, Hermawan, Endang, Rahmawati, \& Dwi, E. (2020). Pengaruh Perencanaan Anggaran Terhadap Penyerapan Anggaran Pada Dinas Penataan Ruang Kota Bandung. Papatung, 3(2), 27-35.

Engkus, Suparman, Nanang, Trisakti, F., Rodhiya, \& Robby, M. (2019). Implementasi Keterbukaan Informasi Publik Di Universitas Islam Negeri Sunan Gunung Djati Bandung. 24-46.

Erawan, P. A. D. I., Wira, S., Santosa, A. D. I., Beny, D. K., Tedy, I. P., \& Wahyudi, A. (2018). Peranan Value For Money untuk Mengukur Kinerja Pemerintahan Kabupaten Buleleng. 8(3), 187-193.

Fitrianda, M. I. (2013). Digital Digital Repository Repository Universitas Universitas Jember Jember Digital Digital Repository Repository Universitas Universitas Jember. 88349033(83).

Hardani, Auliya, N. H., Andriani, H., Fardani, R. A., Ustiawaty, J., Utami, E. F., ... Istiqomah, R. R. (2017). Metode Penelitian Kualitatif dan Kuantitatif. In Journal of Chemical Information and Modeling.

Ihyaul Ulum. (2008). Akuntansi Sektor Publik. malang: UMM PRESS.

Kaharti, E. (2019). Evaluasi Prosedur Penyusunan Anggaran dan Penetapan Anggaran. $08(02), 1-6$.

Kornek, U., \& Edenhofer, O. (2020). The strategic dimension of financing global public goods. European Economic Review, 127, 103423. https://doi.org/10.1016/j.euroecorev.2020.103423

Kusumasari, B., Wicaksono, K. W., Sidik, F., Achyani, F. T., Gana, F., Kiwang, A. S., \& Pandie, D. B. W. (2015). Akuntabilitas Organisasi Sektor Publik. Kebijakan Dan Administrasi Publik, 19, 1-16.

Novianto, D. (2019). Peraturan Pemerintah Tentang Dana Desa (1st ed.; Claudia, Ed.). Kalimantan Barat: CV Derwati Press.

Novitaningrum, B. D. (2014). Akuntabilitas dan Transparansi Pengadaan Barang dan Jasa Pemerintah Melalui Electronic Procurement ( Best Practice di Pemerintah Kota Surabaya ). Kebijakan Dan Manajemen Publik, 2(1), 200-210.

Nurdinawati, E. (2019). Menuju Desa Siaga Bencana: Alam, Nonalam, dan Sosial (S. Teguh, Ed.). Yogyakarta: CV. Hijaz Pustaka Mandiri. 
Online, S. S. G. (2016). 1500 Rumah di Cibiruhilir Terendam Banjir. Retrieved from https://sumedang.online/2016/06/1500-rumah-di-cibiruhilir-terendam-banjir/

Presiden Republik Indonesia. (2007). Undang-Undang Nomor 24 Tahun 2007 tentang Penanggulangan Bencana.

Presiden Republik Indonesia. (2014). Undang-Undang Nomor 6 Tahun 2014 Tentang Desa. In Undang-undang.

Rahajeng, A. (2016). Perencanaan Penganggaran Keuangan Daerah. Yogyakarta: Gadjah Mada University Press.

Ramadhan, Aditya, Fedryansyah, Muhamad, Meilany, \& Lenny. (2019). Peran Local Leader Dalam Penanggulangan Bencana Banjir Di Kecamatan Jatinangor. Focus : Jurnal Pekerjaan Sosial, 2(1), 1. https://doi.org/10.24198/focus.v2i1.23114

Rangkuti, F. (2004). Teknik Membedah kasus Bisnis. Analisis SWOT.

Republik Indonesia. Undang-Undang Nomor 17 Tahun 2003 Tentang Keuangan Negara. (2003).

Sa'adah, B. (2015). Akuntabilitas dan Transparansi Anggaran Melalui e-Government. Kebijakan Dan Manajemen Publik Volume, 3(2), 1-10.

Sari, N. C. F. (2014). Prinsip Pengukuran Kinerja Pemerintah Daerah Dengan Menggunakan Prinsip Value For Money (Study Kasus Kabupaten Sumenep Tahun 2010-2013). Jurnal Akuntansi AKUNESA, 3(2686-438), 1-25.

Silalahi, U. (2015). Metode Penelitian Sosial Kuantitatif. Journal of Visual Languages \& Computing.

Siti Nuraeni. (2020). Penerapan Etika Administrasi Publik Sebagai Upaya Dalam Mewujudkan Good Governance. Ilmiah Magister Ilmu Administrasi.

Somantri, A. (2020). Dadang Naser Serius Tangani Banjir Cileunyi. Retrieved from https:/timejabar.com/bandung-raya/2906/dadang-naser-serius-tangani-banjircileunyi.html diakses 1 Januari 2021

Suharno, I. G. B. D. (2018). Mitigasi Bencana Alam. Yogyakarta: Graha Ilmu.

Triyono. (2003). Teknik Sampling Dalam Pelaksanaan Penelitian. Info Kesehatan, 7(1), 64.

Usiono, Utami, T., Nasution, F., \& Meuthia Nanda. (2018). DISASTER MANAGEMENT Persfektif Kesehatan dan Kemanusian. Medan: PERDANA PUBLISHING.

Widayanti, N., \& Aco, F. (2019). Pemanfaatan Dana Desa (DD) di Desa Argomulya Kecamatan Cangkringan Kabupaten Sleman. 3(2), 156-175. 